\title{
The comparative antimicrobial and anticancer of chemical extract from in vitro and in vivo Peperomia pellucida plantlet
}

\author{
Lydia Teoh ${ }^{1 *}$, Nareshwaran Gnanasegaran ${ }^{2}$, Ahmad Faris Mohd Adnan ${ }^{1}$, Rosna Mat Taha ${ }^{1}$ \\ ${ }^{1}$ Institute of Biological Sciences, Faculty of Science, University of Malaya, 50603, Kuala Lumpur, Malaysia. \\ ${ }^{2}$ Department of Restorative Dentistry, Faculty of Dentistry, University of Malaya, 50603 Kuala Lumpur, Malaysia.
}

\section{ARTICLE INFO}

Article history:

Received on: May 27, 2020

Accepted on: October 07, 2020

Available online: March 10, 2021

Key words:

Peperomia pellucida,

In vitro plant gas chromatography-

mass spectrometry,

Antimicrobial,

Anticancer

\begin{abstract}
Plant tissue culture is a promising technique to produce valuable metabolites for treatments against various diseases. In this study, we assessed the chemical compound and medical properties of Peperomia pellucida L. Kunth with special attention toward antibacterial and anticancer activities. The detection of major compounds such as apiol, phytol, phenol, 9-octadecenoic acid (z), and caryophyllene from methanol and ethanol extracts of both in vivo and in vitro grown plants was done through gas chromatography-mass spectrometry analysis. All plant extracts were found to be effective against Staphylococcus aureus, Salmonella typhi, Escherichia coli, and Pseudomonas aeruginosa. Among these, the methanol extracts of in vitro grown plants showed the highest inhibition zone (12.5 mm) against $S$. aureus followed by ethanol extracts of in vitro grown plants $(12 \mathrm{~mm})$ against $S$. typhi and $P$. aeruginosa. Upon testing the extracts on human breast adenocarcinoma cell line (MCF-7) and human lung adenocarcinoma cell lines (A549), ethanol extracts of in vitro grown plants were inhibitive against the proliferation of MCF-7 cells while methanol extracts of in vitro grown plants inhibited the proliferation of A549. The reproducible protocol in this study has the potential for the establishment of selected and standardized plants suitable for the exploitation in various industries such as pharmaceutical industries, agrochemical industries, and food industries.
\end{abstract}

\section{INTRODUCTION}

Plants have been a very important source of medicine for thousands of years. Lately, the interest in utilizing herbal drugs for treatments has increased as herbs belong to natural sources and is generally considered harmless. In many developing countries, the demand and popularity of herbal medicines from plants or animals as an alternative to modern medicine are increasing day by day as they are readily accessible to rural folk in addition to having an advantage in cost and safety factors. In herbal medicine, all parts of the plant such as the seeds, stems, flowers, leaves, roots, barks, as well as their respective extracts are explored for medicinal purposes [1-3].

Conventionally, many people forage herbal plants through open spaces and forests. This practice may damage the ecological site if not performed correctly. Alternatively, many of the medicinal plants can and have been commercially propagated through plant cell and tissue culture [4]. To this end, plant tissue culture techniques offer an alternative potential sources of producing valuable bioactive compounds through manipulations of the culture environment and plant growth hormones $[5,6]$.

\footnotetext{
*Corresponding Author

Lydia Teoh,

Institute of Biological Sciences, Faculty of Science,

University of Malaya, 50603, Kuala Lumpur, Malaysia.

E-mail: teoh_lydia64@yahoo.com
}

The most researched natural products are the phenolic compounds, studied primarily for their bioactive properties, which have immense structural and chemical diversity and that are produced naturally by plants. Through plant tissue culture techniques, generating and growing in vitro cultures in a controlled environment could challenge the plant biochemical systems to produce novel metabolites. Due to this reason, choosing phenolic compounds from in vitro cultures will provide the required stress conditions for their production and increase the secretion of secondary metabolites through plant tissue culture activities [7].

Peperomia pellucida L. Kunth. is a heart-shaped leaf plant that belongs to the Piperaceae family. This plant can be found in various parts of the world, throughout tropical and subtropical regions. It generally grows in clumps and thrives in loose humid soils [8,9]. This family comprises more than 12 genera and this flowering plant is one of the most widely distributed families [10]. P. pellucida is a common fleshy tropical annual shallow-rooted herb. It typically grows to a height of about $15-45 \mathrm{~cm}$ [11].

P. pellucida has been highly regarded for its medicinal value and is used as a traditional medicine worldwide. The whole plant parts of $P$. pellucida are used to treat different diseases [12]. Many believe that the whole plant contains the therapeutic value to treat many diseases such as fever, headache, gout, fatigue, colic, acne, abscesses, skin diseases, and eye inflammation [13-15]. Studies have reported that $P$. pellucida has additional biological properties 
such as antibacterial [16,17], antifungal [18], antioxidant [19], anti-amoebic [20], anti-ulcer, anti-neoplastic, and anti-inflammatory properties [11,21]. Studies have revealed hundreds of chemical compounds from this herb [22]. Many chemical compounds were isolated from the essential oil of the Piperaceae family. It is also known that $P$. pellucida contains flavonoids, steroids, saponin, tannin, triterpenoid, and phytol $[9,23,24]$.

Despite all the attractions this plant receives, there are inadequate reports on scientific investigation and plant tissue culture to determine the therapeutic potential and medicinal property of this plant as compared to other medicinal plants. Therefore, the present study reports the activities of bioactive compounds from P. pellucida obtained through naturally grown plantlets (in vivo) and plantlets generated through tissue culture (in vitro). We identified the compounds through gas chromatography-mass spectrometry (GC-MS) and tested for antimicrobial and anticancer properties.

\section{MATERIALS AND METHODS}

\subsection{Plant Material}

P. pellucida plants were collected and identified from a population growing at the Institute of Biological Science's garden at the University of Malaya (UM) as well as from various areas around the UM. The plants were then maintained at the Institute of Biological Sciences garden at the Faculty of Science, UM, Kuala Lumpur, Malaysia. The voucher specimens were deposited in the UM Herbarium (KLU), Kuala Lumpur, Malaysia, for identification. The intact plants without the roots were collected in the year 2017 from the ISB garden at the $\mathrm{UM}$, and the in vitro regenerated plantlets of P. pellucida grown on MS medium were used as a comparison.

\subsection{In vitro Regeneration of $P$. pellucida}

Above ground, vegetative shoots of P. pellucida were collected from the ISB garden, UM. The plants were first washed under running tap water for $30 \mathrm{~min}$. Then, the plants were soaked and washed with three drops of teepol with sterile distilled water for $2 \mathrm{~min}$ and rinsed thoroughly 5 times with sterile distilled water. Next, the plants' surfaces were sterilized with $50 \%$ sterile sodium hypochlorite for $2 \mathrm{~min}$, followed by a $50 \%$ disinfectant solution (Dettol, Reckitt Benckiser) for $10 \mathrm{~min}$. This was followed by rinsing the plant 5 times with sterile distilled water. Finally, the P. pellucida plants were treated with an antifungal, $0.01 \%(\mathrm{w} / \mathrm{v})$ carbendazim diluted in $70 \%$ $(\mathrm{v} / \mathrm{v})$ ethanol for $30 \mathrm{~s}$ and rinsed 5 times with sterile distilled water. Then, the sterilized internodes were tapped dry using sterile tissue paper and intersected small pieces $(10 \mathrm{~mm})$ were cultured onto the MS basal medium [25] comprised of $30 \mathrm{~g} / \mathrm{L}$ sucrose (System), $4.4 \mathrm{~g} / \mathrm{L} \mathrm{MS}$ powder (Duchefa Biochemie), $3.3 \mathrm{~g} / \mathrm{L}$ gelrite (Duchefa Biochemie), and $0.01 \%$ carbendazim, adjusted to $\mathrm{pH} 5.7$ before being autoclaved at $121^{\circ} \mathrm{C}$ for $20 \mathrm{~min}$. Cultures were maintained at $25 \pm 2{ }^{\circ} \mathrm{C}, 16 \mathrm{~h} / 8 \mathrm{~h}$ (light/ dark) photoperiod with $25 \mu \mathrm{mol} \mathrm{m}-2 \mathrm{~s}-1$ of light intensity.

\subsection{Extraction of Plant Material}

The harvested in vivo or in vitro generated plants were separately washed clean from soil or media. The clean, intact plants were freezedried, after which the dried samples were ground to a uniform powder and sorted out according to size using $250 \mu \mathrm{m}$ sieves. In brief, dry powdered plant material $(10 \mathrm{~g})$ was weighed out and filled into a cellulose extraction thimble (Whatman), then inserted into a Soxhlet apparatus and extracted with $300 \mathrm{~mL}$ ethanol (R\&M Chemicals) for $48 \mathrm{~h}$ or methanol (R\&M Chemicals). Separately, all the extracts were then concentrated using a rotary evaporator under reduced pressure at $20^{\circ} \mathrm{C}$, relatively low temperature and kept in an airtight container and preserved at $-20^{\circ} \mathrm{C}$ until further use.

\subsection{Analysis of Plant Extracts Chemical Composition}

The phytochemical components of the P. pellucida extractions were identified using Agilent GC-MS. GC-MS was carried out on a 7890A GC/MS Agilent 5975, Shimadzu QP2010 ULTRA GCMS equipped with RTX-5 column. Sample injected: $2 \mu$. The oven column temperature was pre-set at $60^{\circ} \mathrm{C}$, with an initial hold time of $2 \mathrm{~min}$, to $280^{\circ} \mathrm{C}$ at the rate of $5^{\circ} \mathrm{C} / \mathrm{min}$ with a final hold time of $9 \mathrm{~min}$. The injector temperature was set to $240^{\circ} \mathrm{C}$. The total $\mathrm{GC}$ running time was $47 \mathrm{~min}$. Interpretation of GC-MS was conducted, using the National Institute Standard and Technology Version - Year 2011 library. The name, retention time, molecular weight, and molecular structure of the compounds of the test substances were ascertained using the database.

\subsection{Antimicrobial Activity}

All the isolated bacteria were provided by the Microbiology Laboratory at the Institute of Biological Sciences, Faculty of Science, UM. The microorganisms used in this study are as follows: Salmonella typhi, Pseudomonas aeruginosa, Escherichia coli, and Staphylococcus aureus. All the bacteria were cultured in Nutrient broth (Difco) and incubated for $24 \mathrm{~h}$ at $37^{\circ} \mathrm{C}$. The disk diffusion method by Bauer et al. [26] was used with slight modification. A crude extract of in vivo and in vitro grown plants was diluted in distilled water to a concentration of $10 \mathrm{mg} / \mathrm{mL} .10 \mathrm{mg} / \mathrm{mL}$ of chloramphenicol (Duchefa Biochemie) was also prepared as a positive control for bactericidal activity. Sterile blank disks sized $6 \mathrm{~mm}$ in diameter (Oxoid) were impregnated with $20 \mu \mathrm{L}$ of each diluted extract and chloramphenicol. The impregnated disks were allowed to fully dry in the laminar flow before the application on the bacterial lawn. The $10^{-9}$ serially diluted bacteria were aseptically swabbed on the surface of sterile $4 \%$ nutrient agar (Difco) prepared plates using sterile cotton swabs. Using sterile forceps, aseptically, the prepared antibiotic disks were placed over the bacteria seeded agar plates. The disks were separated sufficiently from each other to avoid overlapping of inhibition zones. The plates were then incubated at $37^{\circ} \mathrm{C}$ for $24 \mathrm{~h}$. Finally, antibacterial activity was expressed as the mean zone inhibition diameter $(\mathrm{mm})$ produced by the extract.

\subsection{Anticancer Activity}

To test the anticancer properties, both the methanol-extracted and ethanol-extracted compounds from in vitro and in vivo conditions were prepared in seven different concentrations, serially diluted with a dilution factor of two. As such, the final concentrations of each condition were as follows: $30 \mu \mathrm{g} / \mathrm{mL}, 15 \mu \mathrm{g} / \mathrm{mL}, 7.5 \mu \mathrm{g} / \mathrm{mL}$, $3.75 \mu \mathrm{g} / \mathrm{mL}, 1.875 \mu \mathrm{g} / \mathrm{mL}, 0.9375 \mu \mathrm{g} / \mathrm{mL}$, and $0.469 \mu \mathrm{g} / \mathrm{mL}$.

The cell culture works were performed as described previously with a slight modification [27]. The anticancer properties of extracted compounds were tested on two different types of commercially available cancer cell lines, namely adenocarcinomic human alveolar basal epithelial cells (A549, ATCC, USA) and human breast adenocarcinoma cell lines (MCF-7, ATCC, USA). They were seeded at 1000 cells/100 uL/well in a 96 well plate format (Corning, USA). The anticancer effects of the aforementioned compounds were evaluated by utilizing a viability assay using $10 \%$ Alamar Blue reagent (Thermo Fisher Scientific, MA, USA). Cell viability was analyzed through absorbance at $450 \mathrm{~nm}$ with a reference wavelength set at $590 \mathrm{~nm}$ by the Tecan microplate reader (Infinite 200 PRO Tecan, Life Sciences, 
Switzerland). From the viability profile, the respective half-maximal inhibitory concentration $\left(\mathrm{IC}_{50}\right)$ was calculated from the general equation $\mathrm{y}=\mathrm{mx}+\mathrm{c}$ to indicate the toxicity level of each compound. All assays were performed in triplicates to ensure consistency.

\subsection{Statistical Analysis}

For the antimicrobial study, data were collected and statistically analyzed using Duncan's Multiple Range Test. It should be noted that the mean with different letters in the same column indicates a significant difference with $P<0.05$. For the anticancer study, data were collected and analyzed using two-way ANOVA with Tukey's post-hoc.

\section{RESULTS AND DISCUSSION}

\subsection{Analysis of Plant Extracts Chemical Composition}

In the recent study, GC-MS analysis had identified the presence of phytochemical compounds in both ethanol and methanol extracts of in vivo and in vitro grown $P$. pellucida. The ethanol extract of the in vitro grown $P$. pellucida yielded 24 constituents [Table 1], while the ethanol extract of the in vivo grown $P$. pellucida only yielded 23 constituents [Table 2]. For the methanol extract of in vitro grown, P. pellucida gave rise to 13 constituents from the chromatogram of the extract [Table 3], while the methanol extract of in vivo grown P. pellucida yielded a total of 15 constituents [Table 4]. At present, no studies are reporting the antibacterial activity using extracts from tissue cultured (in vitro) P. pellucida plants. Our study is the first ever to report the constituents of phytochemical compounds from tissue cultured (in vitro) P. pellucida plants. Since methanol and ethanol are efficient in traversing cell walls and seed pods which have more unipolar character and would cause cells to release their chemical compounds, thus they are chosen for extraction. The number of chemical compounds extracted varied depending on the usage of different materials and solvents. The chemical constituents obtained showed that solvent polarity influenced the outcome of the extraction process as the solubility of components depends on the number, type, and linkage position of the compound $[28,29]$.

The ethanol extracts from in vivo and in vitro grown plants showed a greater number of chemical compounds as compared to methanol extracts and these identified compounds possessed biological properties. This shows that $P$. pellucida contains more non-polar compounds that are more readily extracted with ethanol compared to methanol. A comparison was done between the extracts and it was found that certain compounds that are identified in ethanol and methanol extracts of in vitro and in vivo grown plants are nearly similar. For instance, in this study, apiol was found in all the extracts. However, the apiol content was found to be higher in ethanol extracts of in vitro and in vivo grown plants compared to methanol extracts. Previous studies have reported the presence of apiol in the ethanolic extracts [29] and in the essential oil of in vivo grown plants [9,18,30,31]. Apiol was reported to have antifungal activities against Trichophyton mentagrophytes $[21,32]$ and interestingly, it is also used as birth control as well as to treat menstrual disorder [33].

Table 1: GC-MS of ethanol extract analysis revealed the presence of phytochemical components in in vitro grown Peperomia pellucida.

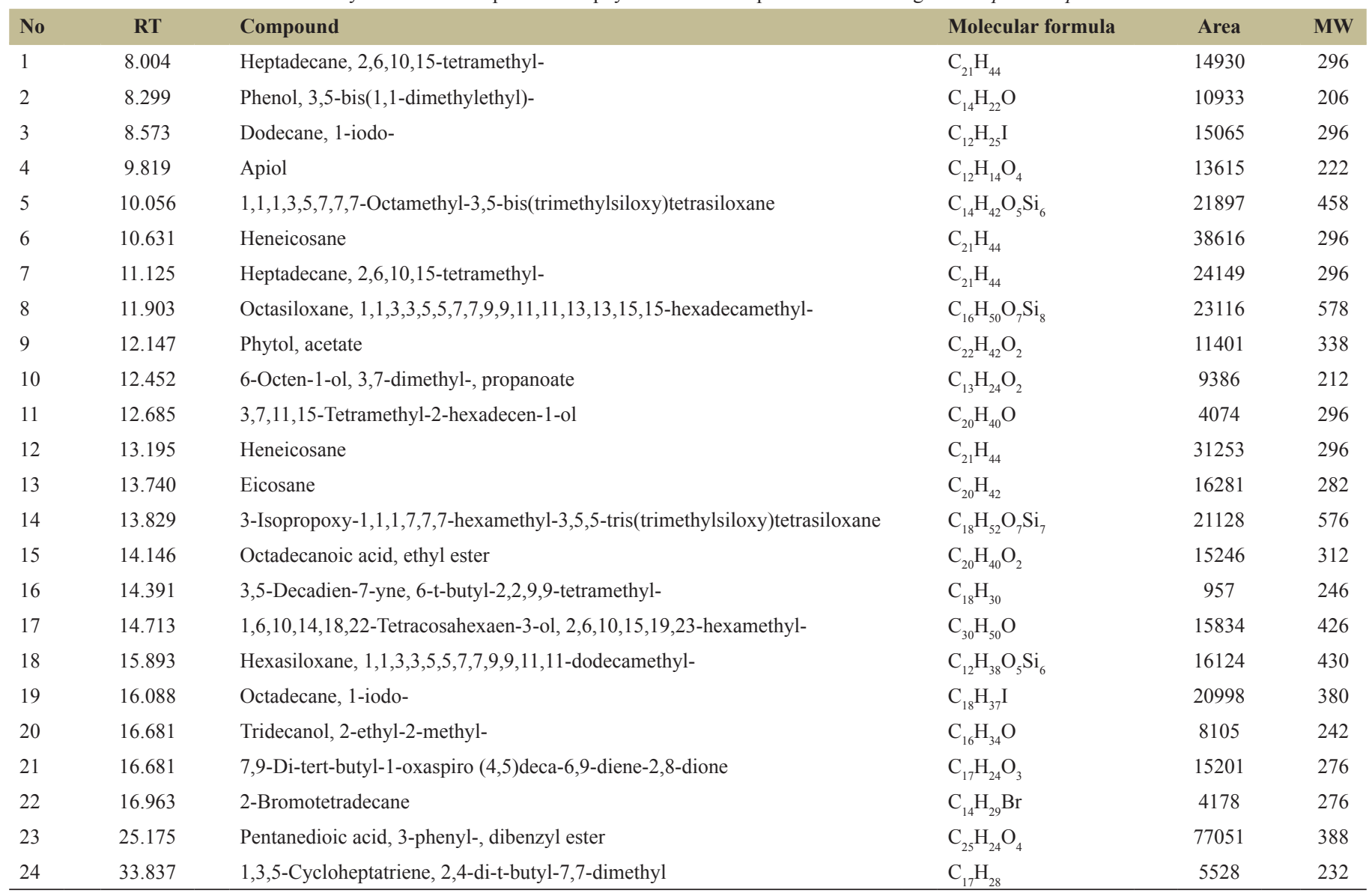

Retention time (RT) and molecular weight (MW). GC-MS: Gas chromatography-mass spectrometry 
Table 2: GC-MS of ethanol extract analysis revealed the presence of phytochemical components in in vivo grown Peperomia pellucida.

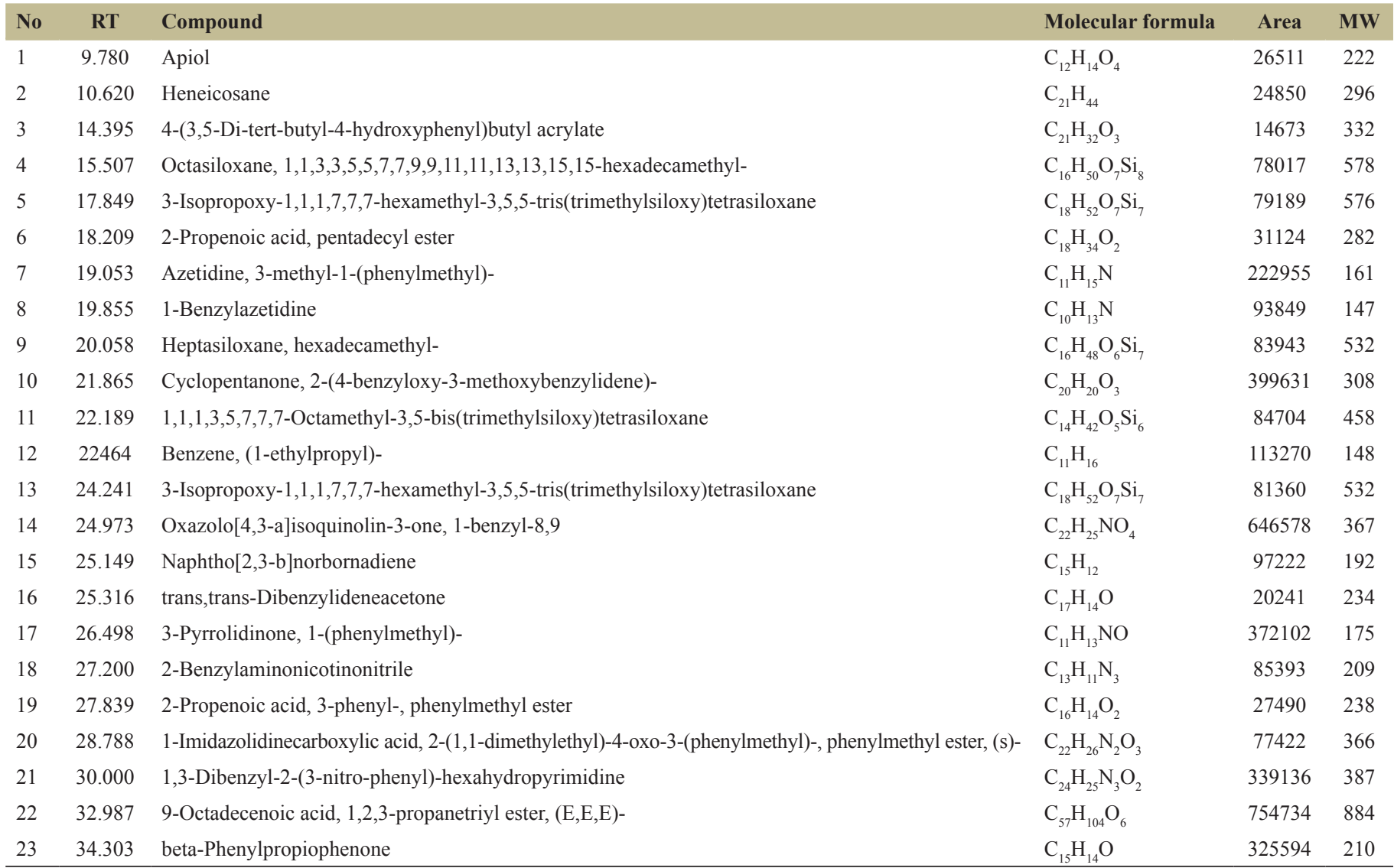

Retention time (RT) and molecular weight (MW). GC-MS: Gas chromatography-mass spectrometry

Table 3: GC-MS of methanol extract analysis revealed the presence of phytochemical components in in vitro grown Peperomia pellucida.

\begin{tabular}{|c|c|c|c|c|c|}
\hline No & RT & Compound & Molecular formula & Area & MW \\
\hline 1 & 6.939 & Cyclohexane, 1-ethenyl-1-methyl-2,4-bis(1-methylethenyl)- & $\mathrm{C}_{15} \mathrm{H}_{24}$ & 920 & 204 \\
\hline 2 & 7.295 & Caryophyllene & $\mathrm{C}_{15} \mathrm{H}_{24}$ & 9467 & 204 \\
\hline 3 & 8.031 & Octadecane, 1-chloro- & $\mathrm{C}_{18} \mathrm{H}_{37} \mathrm{Cl}$ & 15936 & 288 \\
\hline 4 & 8.336 & (7a-Isopropenyl-4,5-dimethyloctahydroinden-4-yl)methanol & $\mathrm{C}_{15} \mathrm{H}_{26} \mathrm{O}$ & 15000 & 222 \\
\hline 5 & 8.612 & Heptadecane, 2,6,10,15-tetramethyl- & $\mathrm{C}_{21} \mathrm{H}_{44}$ & 5219 & 296 \\
\hline 6 & 9.053 & 1,2-Dimethoxy-4-(2-methoxyethenyl)benzene & $\mathrm{C}_{11} \mathrm{H}_{14} \mathrm{O}_{3}$ & 20096 & 194 \\
\hline 7 & 9.829 & Apiol & $\mathrm{C}_{12} \mathrm{H}_{14} \mathrm{O}_{4}$ & 1994 & 222 \\
\hline 8 & 10.663 & Octadecane & $\mathrm{C}_{18} \mathrm{H}_{38}$ & 9479 & 254 \\
\hline 9 & 11.156 & Dodecane, 1-iodo- & $\mathrm{C}_{21} \mathrm{H}_{44}$ & 15003 & 296 \\
\hline 10 & 13.227 & Hexadecane, 1-iodo- & $\mathrm{C}_{12} \mathrm{H}_{25} \mathrm{I}$ & 14503 & 352 \\
\hline 11 & 13.772 & Eicosane & $\mathrm{C}_{20} \mathrm{H}_{42}$ & 11266 & 282 \\
\hline 12 & 16.116 & Tridecanol, 2-ethyl-2-methyl- & $\mathrm{C}_{16} \mathrm{H}_{34} \mathrm{O}$ & 3024 & 352 \\
\hline 13 & 16.710 & Pentadecane, 8-hexyl- & $\mathrm{C}_{21} \mathrm{H}_{44}$ & 9511 & 296 \\
\hline
\end{tabular}

Retention time (RT) and molecular weight (MW). GC-MS: Gas chromatography-mass spectrometry

Apart from apiol, the present study identified the presence of phenolic compounds in the ethanol extracts of in vitro grown plants and methanol extracts of in vivo grown plants, as reported previously [34]. The current study reported that the detection of cyclohexane, 1-ethenyl-1-methyl2,4-bis(1-methylethenyl)-, and caryophyllene was in the methanol extracts of in vitro and in vivo grown P. pellucida. Narayanamoorthi et al. [35] had reported the presence of cyclohexane, 1-ethenyl-1-methyl2,4-bis(1-methylethenyl)-, and caryophyllene in the ethanol extract of an in vivo grown $P$. pellucida whole plant. These two compounds have shown to be effective as an anticancer, analgesic, antibacterial, antiinflammatory, sedative, and also as a fungicide [22,35].

Furthermore, detected was the presence of 9-octadecenoic acid in the ethanol extract of in vivo grown P. pellucida. Omotoso et al. [36] had reported that 9-octadecenoic acid (z) contains anticancer properties, acts as a lubricant, as an anti-inflammatory agent, able to inhibit hemolytic 
5- $\alpha$ reductase, acts as a diuretic agent, able to stimulate immune system, antiandrogenic, antifungal, antibacterial, and lipoxygenase inhibitor activities. Decane is normally used in chemical tests as a function of concentration and temperature [37]. In the present study, the detection of phytol is positive in both the ethanol extract of in vitro grown plants and methanol extract of in vivo grown P. pellucida. Narayanamoorthi et al. [29] reported the presence of phytol in the ethanolic extract of the in vivo grown plant, while Wei et al. [38] reported phytol in the methanol extract of an in vivo grown plant. Whereas, Okoh et al. [39] reported the presence of phytol in essential oil. Previous research has shown that phytol is known to have antimicrobial, anticancer, diuretic, and antiinflammatory activities [22].

In a previous study, Wei et al. [38] had reported the presence of phytol, 2- naphthalenol, decahydro-, hexadecanoic acid, 9,12-octadecadienoic acid, and methyl ester from methanol extraction of in vivo grown P. pellucida. Verma et al. [9] has reported the detection of a total of 50 compounds from the essential oil of P. pellucida. Among the 50 compounds, apiol was also present in the essential oil. A separate study reported the presence of dillapiole in P. pellucida extract and tested on Wistar rats for gastroprotection. The findings have concluded that dillapiole is the most active gastroprotective agent of $P$. pellucida [8].

\subsection{Antibacterial Activity}

P. pellucida has known to be a medicinal plant and is widely used for skin, eye, throat, and gout as well as for antibacterial activity. In the present study, ethanolic and methanolic extracts of in vivo and in vitro grown plants were found to be effective against the following bacteria: S. typhi, P. aeruginosa, E. coli, and S. aureus [Table 5]. Tests of the

Table 4: GC-MS of methanol extract analysis revealed the presence of phytochemical components in in vivo grown Peperomia pellucida.

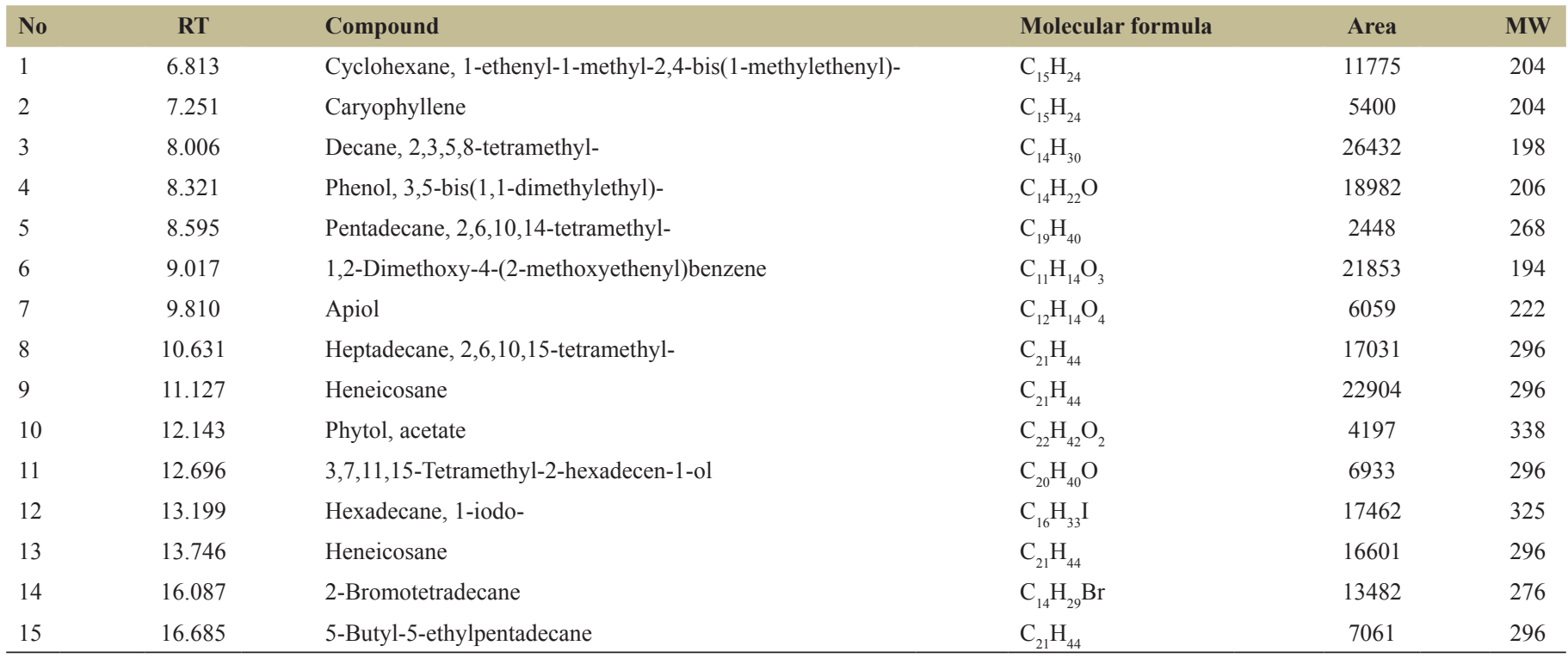

Retention time (RT) and molecular weight (MW). GC-MS: Gas chromatography-mass spectrometry

Table 5: Antibacterial activities of ethanolic and methanolic extracts of in vivo and in vitro Peperomia pellucida.

\begin{tabular}{|c|c|c|c|c|c|}
\hline \multirow[t]{2}{*}{ Solvent } & \multicolumn{4}{|c|}{ Zone of inhibition $(\mathrm{mm})$ and concentration } & \multirow[t]{2}{*}{ Reference } \\
\hline & Staphylococcus aureus & Escherichia coli & Salmonella typhi & Pseudomonas aeruginosa & \\
\hline \multirow[t]{5}{*}{ Methanol } & $\begin{array}{c}11.00(10 \mathrm{mg} / \mathrm{mL}) \\
12.50(\mathrm{IVT})(10 \mathrm{mg} / \mathrm{mL})\end{array}$ & $\begin{array}{c}9.50(10 \mathrm{mg} / \mathrm{mL}) \\
10.00(\mathrm{IVT})(10 \mathrm{mg} / \mathrm{mL})\end{array}$ & $\begin{array}{c}11.75(10 \mathrm{mg} / \mathrm{mL}) \\
11.25 \text { (IVT) }(10 \mathrm{mg} / \mathrm{mL})\end{array}$ & $\begin{array}{c}10.00(10 \mathrm{mg} / \mathrm{mL}) \\
7.50(\mathrm{IVT})(10 \mathrm{mg} / \mathrm{mL})\end{array}$ & Current study \\
\hline & NI $(1 \mathrm{mg} / \mathrm{mL})$ & $8.00(1 \mathrm{mg} / \mathrm{mL})$ & $25.00(1 \mathrm{mg} / \mathrm{mL})$ & $20.00(1 \mathrm{mg} / \mathrm{mL})$ & {$[42]$} \\
\hline & $\begin{array}{l}10.00(200 \mathrm{mg} / \mathrm{mL}) \\
\mathrm{NI}(25-100 \mathrm{mg} / \mathrm{mL})\end{array}$ & $\begin{array}{c}10.00(200 \mathrm{mg} / \mathrm{mL}) \\
\mathrm{NI}(25-100 \mathrm{mg} / \mathrm{mL})\end{array}$ & $\begin{array}{c}10.00(200 \mathrm{mg} / \mathrm{mL}) \\
\mathrm{NI}(25-100 \mathrm{mg} / \mathrm{mL})\end{array}$ & $\begin{array}{c}10.00(200 \mathrm{mg} / \mathrm{mL}) \\
\mathrm{NI}(25-100 \mathrm{mg} / \mathrm{mL})\end{array}$ & {$[48]$} \\
\hline & $\begin{array}{c}10.00(200 \mathrm{mg} / \mathrm{mL}) \\
\mathrm{NI}(6.25-100 \mathrm{mg} / \mathrm{mL})\end{array}$ & $\begin{array}{c}10.00(200 \mathrm{mg} / \mathrm{mL}) \\
\mathrm{NI}(6.25-100 \mathrm{mg} / \mathrm{mL})\end{array}$ & $\begin{array}{c}10.00(200 \mathrm{mg} / \mathrm{mL}) \\
\mathrm{NI}(6.25-100 \mathrm{mg} / \mathrm{mL})\end{array}$ & $\begin{array}{c}12.00(200 \mathrm{mg} / \mathrm{mL}) \\
\mathrm{NI}(6.25-50 \mathrm{mg} / \mathrm{mL})\end{array}$ & {$[34]$} \\
\hline & $8.00(4 \mathrm{mg} / \mathrm{disc})$ & $12.00(4 \mathrm{mg} / \mathrm{disc})$ & $10.00(4 \mathrm{mg} / \mathrm{disc})$ & $10.00(4 \mathrm{mg} / \mathrm{disc})$ & {$[49]$} \\
\hline \multirow[t]{5}{*}{ Ethanol } & $\begin{array}{c}6.75(10 \mathrm{mg} / \mathrm{mL}) \\
10.75(\mathrm{IVT})(10 \mathrm{mg} / \mathrm{mL})\end{array}$ & $\begin{array}{c}11.50(10 \mathrm{mg} / \mathrm{mL}) \\
8.00(\mathrm{IVT})(10 \mathrm{mg} / \mathrm{mL})\end{array}$ & $\begin{array}{c}9.25(10 \mathrm{mg} / \mathrm{mL}) \\
12.00(\mathrm{IVT})(10 \mathrm{mg} / \mathrm{mL})\end{array}$ & $\begin{array}{c}10.75(10 \mathrm{mg} / \mathrm{mL}) \\
12.00(\mathrm{IVT})(10 \mathrm{mg} / \mathrm{mL})\end{array}$ & Current study \\
\hline & $6.00(100 \mathrm{mg} / \mathrm{mL})$ & $5.00(100 \mathrm{mg} / \mathrm{mL})$ & Not performed & Not performed & {$[19]$} \\
\hline & Not performed & $10.00(100 \mathrm{ug} / \mathrm{mL})$ & Not performed & $14(100 \mathrm{ug} / \mathrm{mL})$ & {$[50]$} \\
\hline & $6.33(250 \mathrm{mg} / \mathrm{mL})$ & $\mathrm{NI}(250 \mathrm{mg} / \mathrm{mL})$ & $6.33(250 \mathrm{mg} / \mathrm{mL})$ & Not performed & {$[18]$} \\
\hline & Not performed & $12.00(10 \mathrm{mg} / \mathrm{mL})$ & Not performed & $19.6(10 \mathrm{mg} / \mathrm{mL})$ & {$[10]$} \\
\hline Chloramphenicol (Control) & $16.75(10 \mathrm{mg} / \mathrm{mL})$ & $17.00(10 \mathrm{mg} / \mathrm{mL})$ & $15.75(10 \mathrm{mg} / \mathrm{mL})$ & $17.00(10 \mathrm{mg} / \mathrm{mL})$ & Current study \\
\hline
\end{tabular}

In vitro (IVT), No inhibition (NI) 
extracts against several organisms have displayed comparable results that of the standard antibiotics, chloramphenicol. The GC-MS chemical analysis result of $P$. pellucida shown it to contain bioactive compounds and has been reported to exhibit antibacterial activities [22,35,38]. Based on Table 5 in the current study, the methanol extract from an in vitro plant showed the highest inhibition zones $(12.5 \mathrm{~mm})$ against $S$. aureus with a lower concentration compared to the in vivo grown plant extracts from other studies. The ethanol extracts from an in vivo grown plant $(6.75 \mathrm{~mm})$ and in vitro grown plant $(10.75 \mathrm{~mm})$ showed a contrasting result with the methanol extract from an in vitro grown plant, which was less effective against $S$. aureus. This result is also highly comparable to previous studies [Table 5]. S. aureus is a major human pathogen that affects the skin and soft tissues, pleuropulmonary, bloodstream respiratory tract, and can also contaminate medical devices [40,41]. In treating multiple resistant $S$. aureus (MRSA), there are proposals for the usage of the methanol extract of the in vitro grown plant. The methanol extract of the in vitro grown P. pellucida can be a promising potential inhibitor against MRSA. GC-MS analysis of the methanol extract from the in vitro grown plant has detected the presence of previously described antimicrobial agents such as Cyclohexane, 1-ethenyl-1-methyl-2,4-bis(1-methylethenyl)-, and Caryophyllene. However, in the current study, the ethanol extract from the in vitro plant showed the highest inhibition zones $(12 \mathrm{~mm})$ against $S$. typhi and P. aeruginosa compared to methanol extracts from in vivo and in vitro grown plants or the ethanol extract from in vivo grown plants. In the current study, the ethanol extract from the in vivo grown plant showed greater activity $(11.5 \mathrm{~mm})$ against $E$. coli compared to the ethanol extract from an in vitro grown plant $(8.00 \mathrm{~mm})$. A study conducted by Edewor-Kuponiyi [42] showed that the crude methanol extract from the in vivo grown leaves at $1 \mathrm{mg} / \mathrm{mL}$ concentration showed a higher inhibition zone compared to the current study. Edewor-Kuponiyi used dimethyl sulfoxide (DMSO) to dissolve the extracts. A study reported DMSO could inhibit the growth of bacteria [43]. This implies that the presence of DMSO can enhance the effect of the inhibition zone. At present, no studies are reporting the antibacterial activity using extracts from tissue cultured (in vitro) P. pellucida plants. The results obtained in this study on the antimicrobial efficacy of dried crude extracts of in vitro regenerated $P$. pellucida showed the highest inhibitory activity using ethanol and methanol as the medium of extraction. The plant extracts showed bacteria inhibition. This could be due to the presence of various active compounds such as polyphenols and flavonoids from the plant extracts that could be the antimicrobial components [17]. The topical application of the ethanolic and methanolic extracts of in vivo and in vitro grown plants is possible as both extracts displayed as antibacterial agents. All parts of P. pellucida have potent antibacterial activity and it has also been reported that crude methanol extracts of $P$. pellucida have a broad spectrum of antimicrobial activity [23]. In vivo and in vitro grown plants produce various compounds which show different bioactivity prospectives [44].

Biotechnological methods through plant tissue culture provide a promising bio-production platform for desired natural products. Cultures developed from shoots or roots revealed an undifferentiated metabolic characteristic compared to their parent plant. Tissue culture offers an alternative potential for the fabrication of high-value natural products in the plant [6]. It is important to note that the antimicrobial activities differ in in vivo and in vitro grown plant extracts, probably due to the inherent characteristics of the fully grown plants and the maturity of their chemically active constituents.

\subsection{Anticancer Activity}

Apart from the aforementioned characteristics of $P$. pellucida, the anticancer properties of the said extracts were tested on two commercially available cancer cell lines, namely; adenocarcinomic human alveolar basal epithelial cells (A549) and human breast adenocarcinoma cell lines (MCF-7). As shown in Figure 1, with increasing concentration of both ethanol extracts of in vitro and in vivo grown plants shows a general decrement of the viability of the cells. For instance, at $30 \mu \mathrm{g} / \mathrm{mL}$, the viability of A549 cells has reduced from $100 \%$ to $45.3 \%$. The $\mathrm{IC}_{50}$ of this extract was found to be $13.02 \mu \mathrm{g} / \mathrm{mL}$ based on the equation $y=-7.335 \ln (x)+68.828$ [Figure 1a]. Similarly, the viability of A549 cells was also checked upon exposure to both methanol extracts of in vitro and in vivo grown plants [Figure $1 \mathrm{c}$ and d]. In particular, the viability of A549 cells at $30 \mu \mathrm{g} / \mathrm{mL}$ for both methanol extracts of in vitro and in vivo grown plants were $35.8 \%$ and $33.3 \%$, respectively, hereby indicating the potency of this extract, especially upon methanol extraction. The $\mathrm{IC}_{50}$ for the extracts was found to be $8.11 \mu \mathrm{g} / \mathrm{mL}$ and $6.76 \mu \mathrm{g} / \mathrm{mL}$, respectively.
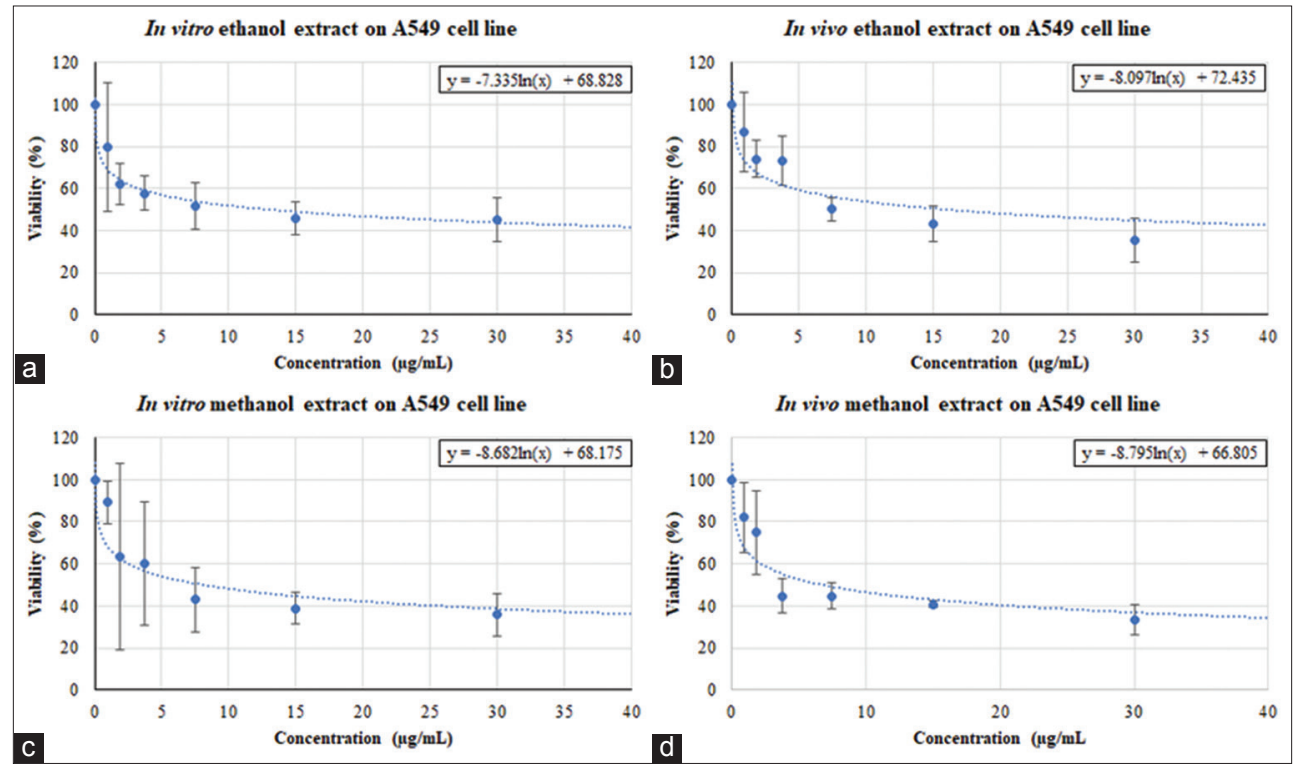

Figure 1: (a-d) Viability assay of A549 cells response 

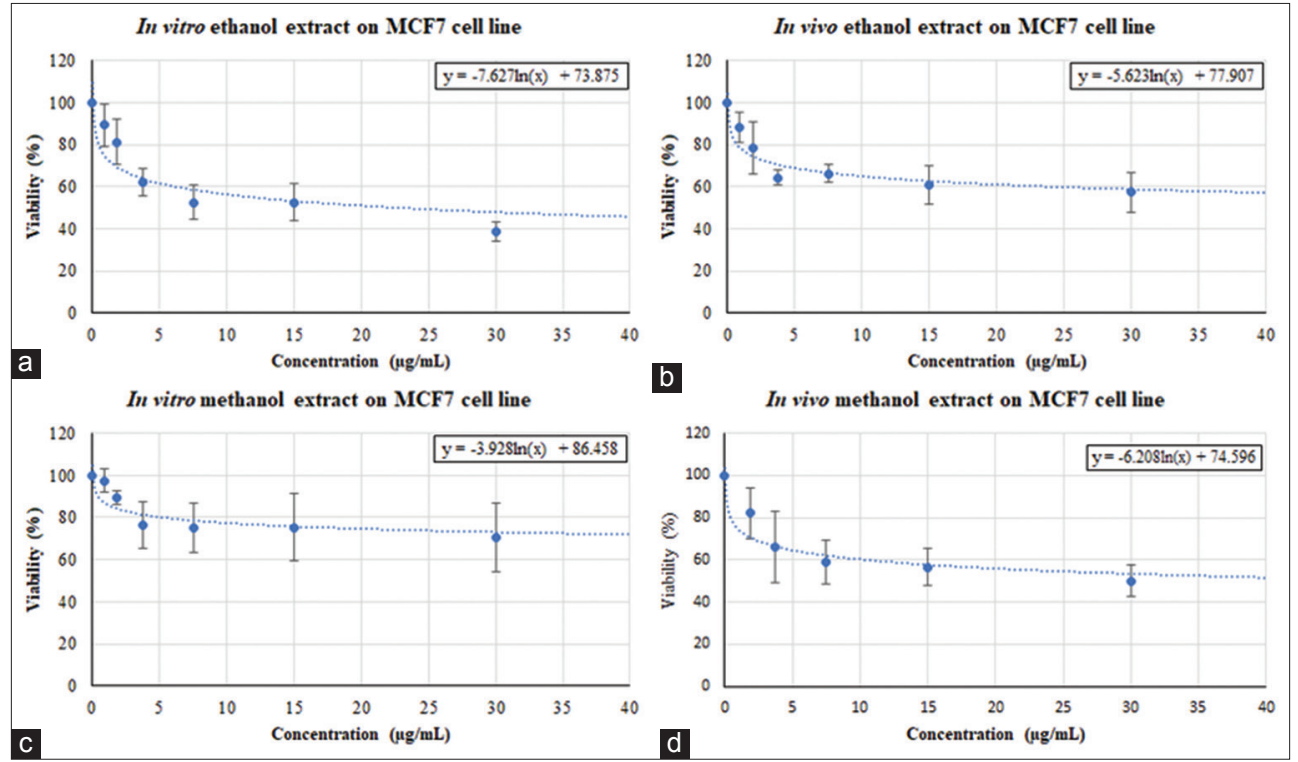

Figure 2: (a-d) Viability assay of MCF7 cells response

In addition to assessing the viability of A549, a similar assay was also conducted on another robust cancer cell line, MCF-7 [Figure 2]. Upon exposure to the ethanol extract from an in vitro grown plant, the viability trend showed a typical decrement with increasing concentration. The observation for the exposure of the $30 \mathrm{~g} / \mathrm{ml}$ extract shows the viability to be at $38.6 \%$ compared to $45.3 \%$ in its $\mathrm{A} 459$ counterpart with $\mathrm{IC}_{50}$ of $22.88 \mathrm{~g} / \mathrm{mL}$ [Figure 2a]. Finally, the viability of MCF7 upon exposure to the methanol extracts from an in vivo grown plant also displayed an augmented survival pattern as compared to its A549 counterpart. For instance, the exposure to $30 \mu \mathrm{g} / \mathrm{mL}$ of the extract revealed a viability percentage of $49.94 \%$, as compared to $33.3 \%$ in A549 cells with $\mathrm{IC}_{50} 52.56 \mu \mathrm{g} / \mathrm{mL}$ [Figure 2c]. A similar study by Wei et al. [38] also confirmed the anticancer findings, thus strengthening the possibility that $P$. pellucida extract can be commercially harnessed for anticancer treatment. Although the study reported a much lower $\mathrm{IC}_{50}$ than our findings, it is believed that this variation could be due to the number of plants used. In this study, two different types of cancer cells, namely adenocarcinomic human alveolar basal epithelial cells (A549) and human breast adenocarcinoma cell lines (MCF-7), were chosen based on the frequent occurrence of such cancers in human [45]. In general, an increase in extract concentration resulted in the poor survival of these cancer cells over time. However, the total effect varied among the type of cancers as well as the origin of the extract being used. For instance, in A549 cells, extracts from methanol resulted in a lower survival rate upon exposure at $30 \mu \mathrm{g} / \mathrm{mL}$ for $24 \mathrm{~h}$. This shows that the presence of more active compounds in the methanolic extracts had displayed higher cytotoxicity on A549 cells as compared to those from ethanol extraction. This was also supported with $\mathrm{IC}_{50}$ values found alongside. Contrastingly, in MCF7 cells, compounds through ethanol extraction presented higher cytotoxicity coupled with lower $\mathrm{IC}_{50}$ values, as compared to those of methanol extraction.

Although this study did not address the possible mechanism behind the cytotoxicity effect of these compounds, it is speculated that key cellular pathways such as TGF- $\beta /$ Smad and PI3K/Akt/mTOR signaling pathways could be one of which the active compounds exert their effects [46]. Further studies could clarify therapeutic potentials and toxicity issues should these compounds move toward clinical and therapeutic usages. Anticancer activities differ in in vivo and in vitro grown plant extracts, probably due to the inherent characteristics of the fully grown plants and the maturity of its chemically active constituents.

\section{CONCLUSION}

Plant tissue culture is a promising technology for producing valuable plant metabolites. GC-MS analysis revealed a total of 24 compounds from in vivo and in vitro grown $P$. pellucida. Both ethanol and methanol extracts of in vivo and in vitro grown $P$. pellucida contained apiol which has proven to contain medicinal properties. Both ethanol and methanol extracts of in vivo and in vitro grown P. pellucida contain numerous chemical compound that may possess medicinal properties. Further investigation is necessary to justify the rationale behind the wide applicability of the plants in herbal medicine.

A comparison was made between extracts from in vitro regenerated plants through tissue culture system and in vivo plants for antibacterial activities. The results obtained indicated that dried crude extracts of in vitro regenerated $P$. pellucida displays antibacterial activities.

Cancer is the most devastating disease and the leading cause of death in many countries. The methanol extract of an in vitro regenerated plant showed better anticancer activity on A549 cells, even though it was not as significant as compared to methanol and ethanol extracts of in vivo grown plants. In MCF-7, the ethanol extracts of in vitro regenerated plants showed the best anticancer activity. The results of this study suggest that extracts from $P$. pellucida contain anticancer properties and have the potential to treat breast and lung cancer.

\section{AUTHORS' CONTRIBUTIONS}

TL: participated in the acquisition of data, analysis, interpretation, prepared figures, and wrote the manuscript; NG, AFMA, and RMT: designed the experiments, participated in data analysis, revised the manuscript critically for important intellectual contents, and agreed to be accountable for all aspects of the work in ensuring that questions related to the accuracy or integrity of any part of the work had been investigated and resolved appropriately. All authors read and approved the final manuscript. 


\section{ACKNOWLEDGMENT}

The authors would like to thank the UM research grant (PG138-2015A) and the government of Malaysia research grant (FP036-2014A).

\section{CONFLICTS OF INTEREST}

The authors declare no competing financial interests exist.

\section{ETHICAL APPROVALS}

This study does not involve experiments on animals or human subjects.

\section{PUBLISHER'S NOTE}

This journal remains neutral with regard to jurisdictional claims in published institutional affiliation.

\section{REFERENCES}

1. Atmakuri LR, Dathi S. Current trends in herbal medicines. J Pharm Res 2010;3:109-13.

2. Upadhayay UP, Ewam PC, Ewam UP, Sansthan GA. Immunomodulatory and therapeutic potentials of herbal, traditional/ indigenous and ethnoveterinary medicines Mahima, Anu Rahal, Rajib Deb, Shyma K. Latheef, Hari Abdul Samad. Pak J Biol Sci 2012;15:754-74.

3. Verma S, Singh S. Current and future status of herbal medicines. Vet World 2008; 1:347-50.

4. Verma SK, Yucesan BB, Cingoz G, Gurel S, Gurel E. Direct shoot regeneration from leaf explants of Digitalis lamarckii, an endemic medicinal species. Turk J Bot 2011;35:689-95.

5. Karuppusamy S. A review on trends in production of secondary metabolites from higher plants by in vitro tissue, organ and cell cultures. J Med Plants Res 2009;3:1222-39.

6. Yue W, Ming QL, Lin B, Rahman K, Zheng CJ, Han T, et al. Medicinal plant cell suspension cultures: Pharmaceutical applications and highyielding strategies for the desired secondary metabolites. Crit Rev Biotechnol 2016;36:215-32.

7. Dias MI, Sousa MJ, Alves RC, Ferreira IC. Exploring plant tissue culture to improve the production of phenolic compounds: A review. Ind Crops Prod 2016;82:9-22.

8. Rojas-Martínez R, Arrieta J, Cruz-Antonio L, Arrieta-Baez D, Velázquez-Méndez AM, Sánchez-Mendoza ME. Dillapiole, isolated from Peperomia pellucida, shows gastroprotector activity against ethanol-induced gastric lesions in Wistar rats. Molecules 2013;18:11327-37.

9. Verma RS, Padalia RC, Goswami P, Chauhan A. Essential oil composition of Peperomia pellucida (L.) Kunth from India. J Essent Oil Res 2015;27:89-95.

10. Akinnibosun HA, Akinnibosun FI, German BE. Antibacterial activity of aqueous and ethanolic leaf extracts of Peperomia pellucida (1.) HB and K. (piperaceae) on three gram-negative Bacteria isolates. Sci World J 2008;3:33-6.

11. Ooi DJ, Iqbal S, Ismail M. Proximate composition, nutritional attributes and mineral composition of Peperomia pellucida L. (Ketumpangan Air) grown in Malaysia. Molecules 2012;17:11139-45.

12. Awe FA, Giwa-Ajeniya AO, Akinyemi AA, Ezeri GN. Phytochemical analysis of Acalypha wilkesiana, Leucaena leucocephala, Peperomia pellucida and Senna alata leaves. Int J Eng Sci 2013;2:41-4.

13. Hamzah RU, Odetola AA, Erukainure OL, Oyagbemi AA. Peperomia pellucida in diets modulates hyperglyceamia, oxidative stress and dyslipidemia in diabetic rats. J Acute Dis 2012;1:135-40.

14. Roslida AH, Aini NZ. Evaluation of gastroprotective effect of the ethanolic extract of Peperomia pellucida (L) Kunth. Pharmacol
Online 2009;2:678-86.

15. Susilawati Y, Nugraha R, Muhtadi A, Soetardjo S, Supratman U. (S)-2-Methyl-2-(4-methylpent-3-enyl)-6-(propan-2-ylidene)-3,4, 6, 7-tetrahydropyrano [4, 3-g] chromen-9 (2H)-one. Molbank 2015;2015:M855.

16. Khan A, Rahman M, Islam S. Isolation and bioactivity of a xanthone glycoside from Peperomia pellucida. Life Sci Med Res 2010;1:1-10.

17. Zubair KL, Samiya JJ, Jalal U, Mostafizur R. In vitro investigation of antdiarrhoeal, antimicrobial and thrombolytic activities of aerial parts of Peperomia pellucida. Pharmacol Online 2015;3:5-13.

18. Igwe OU, Mgbemena NA, Mary A. A chemical investigation and antibacterial activity of the leaves of Peperomia pellucida L. HBK (Piperaceae). Asian J Chem Pharm Sci 2014;2:78-86.

19. Mensah JK, Ihenyen JO, Okhiure MO. Nutritional, phytochemical and antimicrobial properties of two wild aromatic vegetables from Edo state. J Nat Prod Plant Resour 2013;3:8-14.

20. Sangsuwon C, Jirujchariyakul W, Roongruangchai K. Chemical constituents and antiamoebic of methanolic fraction from Peperomia pellucida (Linn.) Kunth. Appl Mech Mater 2015;709:417-21.

21. Majumder P, Abraham P, Satya V. Ethno-medicinal, phytochemical and pharmacological review of an amazing medicinal herb Peperomia pellucida (L.) HBK. Res J Pharm Biol Chem Sci 2011;2:358-64.

22. Kartika IG, Insanu M, Safitri D, Putri CA, Adnyana IK. New update: Traditional uses, phytochemical, pharmacological and toxicity review of Peperomia pellucida (L.) Kunth. Pharmacol Online 2016;31:30-43.

23. Abere T, Okpalaonyagu S. Pharmacognostic evaluation and antisickling activity of the leaves of Peperomia pellucida (L.) HBK (Piperaceae). Afr J Pharm Pharmacol 2015;9:561-6.

24. Mappa T, Edy HJ, Kojong N. Formulasi gel ekstrak daun sasaladahan (Peperomia pellucida (L.) HBK) dan uji efektivitasnya terhadap luka bakar pada kelinci (Oryctolagus cuniculus). Pharmacon 2013;2:49-55.

25. Murashige T, Skoog F. A revised medium for rapid growth and bio assays with tobacco tissue cultures. Physiol Plant 1962;15:473-97.

26. Bauer AW, Kirby WM, Sherris JC, Turck M. Antibiotic susceptibility testing by a standardized single disc method. Am J Clin Pathol 1966;45:493-6.

27. Shaghayegh G, Alabsi AM, Ali-Saeed R, Ali AM, VincentChong VK, Zain RB. Cell cycle arrest and mechanism of apoptosis induction in $\mathrm{H} 400$ oral cancer cells in response to damnacanthal and nordamnacanthal isolated from Morinda citrifolia. Cytotechnology 2016;68:1999-2013.

28. Lapornik B, Prošek M, Wondra AG. Comparison of extracts prepared from plant by-products using different solvents and extraction time. J Food Eng 2005;71:214-22.

29. Pinelo M, Rubilar M, Jerez M, Sineiro J, Núñez MJ. Effect of solvent, temperature, and solvent-to-solid ratio on the total phenolic content and antiradical activity of extracts from different components of grape pomace. J Agric Food Chem 2005;53:2111-7.

30. de Lira PN, da Silva JK, Andrade EH, Sousa PJ, Silva NN, Maia JG. Essential oil composition of three Peperomia species from the Amazon, Brazil. Nat Prod Commun 2009;4:427-30.

31. de Oliveira JC, da Camara CA, Neves RC, Botelho PS. Chemical composition and acaricidal activity of essential oils from Peperomia pellucida Kunth. Against Tetranychus urticae. Rev Virtual Quimica 2017;9:2204-13.

32. Ragasa CY, Dumato A, Rideout JA. Antifungal compounds from Peperomia pellucida. ACGC Chem Res Commun 2017;7:54-61.

33. Daradkeh G, Essa MM. 16 Parsley. In: Ambrose DC, Manickavasagan A, Naik R, editors. Leafy Medicinal Herbs: Botany, Chemistry, Postharvest Technology and Uses. India: CABI; 2016. p. 189-97.

34. Oloyede GK, Onocha PA, Olaniran BB. Phytochemical, toxicity, antimicrobial and antioxidant screening of leaf extracts of Peperomia pellucida from Nigeria. Adv Environ Biol 2011;5:3700-9. 
35. Narayanamoorthi V, Vasantha K, Maruthasalam RR. GC MS determination of bioactive components of Peperomia pellucida (L.) Kunth. Biosci Discov 2015;6:83-8.

36. Omotoso AE, Olorunfemi EO, Mikailu S. Phytochemical analysis of Cnidoscolus aconitifolius (Euphorbiaceae) leaf with spectrometric techniques. Niger J Pharm Appl Sci Res 2014;3:38-49.

37. Hollamby MJ, Smith CF, Britton MM, Danks AE, Schnepp Z, Grillo I, et al. The aggregation of an alkyl-C 60 derivative as a function of concentration, temperature and solvent type. Phys Chem Chem Phys 2018;20:3373-80.

38. Wei LS, Wee W, Siong JY, Syamsumir DF. Characterization of anticancer, antimicrobial, antioxidant properties and chemical compositions of Peperomia pellucida leaf extract. Acta Med Iran 2011;49:670-4.

39. Okoh SO, Iweriebor BC, Okoh OO, Okoh AI. Bioactive constituents, radical scavenging, and antibacterial properties of the leaves and stem essential oils from Peperomia pellucida (L.) Kunth. Pharmacogn Mag 2017;13:S392.

40. Tong SY, Davis JS, Eichenberger E, Holland TL, Fowler VG. Staphylococcus aureus infections: Epidemiology, pathophysiology, clinical manifestations, and management. Clin Microbiol Rev 2015;28:603-61.

41. Lakhundi S, Zhang K. Methicillin-resistant Staphylococcus aureus: Molecular characterization, evolution, and epidemiology. Clin Microbiol Rev 2018;31:e00020-18.

42. Edewor-Kuponiyi TB. Phytochemical and antimicrobial analyses of extracts of Peperomia pellucida (L.). J Pharm Res 2012;5:2934-7.

43. Ansel HC, Norred WP, Roth IL. Antimicrobial activity of dimethyl sulfoxide against Escherichia coli, Pseudomonas aeruginosa and
Bacillus megaterium. J Pharm Sci 1969;58:836-9.

44. Khorasani A, Sani W, Philip K, Taha RM, Rafat A. Antioxidant and antibacterial activities of ethanolic extracts of Asparagus officinalis cv. Mary Washington: Comparison of in vivo and in vitro grown plant bioactivities. Afr J Biotechnol 2010;9:8460-6.

45. Siegel RL, Miller KD, Jemal A. Cancer statistics, 2019. CA Cancer J Clin 2019;69:7-34.

46. Luo Y, Ren Z, Du B, Xing S, Huang S, Li Y, et al. Structure identification of vicenin II extracted from Dendrobium officinale and the reversal of TGF- $\beta 1$-induced epithelial-mesenchymal transition in lung adenocarcinoma cells through TGF- $\beta /$ Smad and PI3K/Akt/ mTOR signaling pathways. Molecules 2019;24:144.

47. Jang HR, Lee HJ, Shohael A, Park BJ, Paek KY, Park SY. Production of biomass and bioactive compounds from shoot cultures of Rosa rugosa using a bioreactor culture system. Hortic Environ Biotechnol 2016;57:79-87.

48. Idris OO, Olatunji BP, Madufor P. In vitro antibacterial activity of the extracts of Peperomia pellucida (L). Microbiol Res J Int 2016;11:1-7.

49. Khan MR, Omoloso AD. Antibacterial activity of Hygrophila stricta and Peperomia pellucida. Fitoterapia 2002;73:251-4.

50. Kalaiarasi V, Johnson M, Janakiraman N, Sivaraman A. Phytochemical and antibacterial studies on Peperomia Pellucida (L.) HBK. Int J Pharm Sci Res 2016;1:4-6.

\section{How to cite this article: \\ Teoh L, Gnanasegaran N, Adnan AFM, Taha RM. The comparative \\ antimicrobial and anticancer of chemical extract from in vitro and in vivo \\ Peperomia pellucida plantlet. J App Biol Biotech. 2021;9(2):115-123.}

DOI: $10.7324 / J A B B .2021 .9210$ 